\title{
A CROSS SECTIONAL STUDY ON NUTRITIONAL STATUS OF PRESCHOOL CHILDREN IN SLUMS OF DIBRUGARH TOWN.
}

Ajanta Deuri, Alak Barua

1. Assistant Professor. Department of Community Medicine, Assam Medical College, Dibrugarh, Assam.

2. Professor. Department of Community Medicine, Assam Medical College, Dibrugarh, Assam.

\author{
CORRESPONDING AUTHOR: \\ Dr. Ajanta Deuri, \\ Dept. of Community Medicine, \\ Assam Medical College, \\ Dibrugarh, Assam, Pin no.-786002. \\ E-mail: deuri.drajanta@gmail.com
}

\begin{abstract}
A cross-sectional study had been carried out in the urban slums of Dibrugarh during July, 2007 to June, 2008 and a total of 316 preschool children (aged one to five years) had been included in the study. The nutritional status of the study subjects had been assessed by anthropometry and for this Z- score approach is utilized. In order to compare the prevalence of malnutrition in different categories, z-test for testing the difference between two proportions had been employed and $\chi^{2}$ - test was utilized for testing the associations. The study revealed that the overall prevalence of underweight, stunting and wasting among the preschool children was $59.37 \%, 53.12 \%$ and $17.81 \%$ respectively. Also, it had been observed that the prevalence of stunting was significantly higher in children of illiterate mothers $(p<0.01)$ and wasting was significantly higher $(\mathrm{p}<0.001)$ amongst the children of working mothers. Underweight and stunting was higher in Class III socioeconomic group $(\mathrm{p}<0.01)$ and wasting was higher in class IV socioeconomic group $(\mathrm{p}<0.05)$ as per modified Kuppuswami's socioeconomic classification. From the present study it had been revealed that illiteracy, lower socioeconomic status and working status of the mother had a negative impact on the nutritional status of their children. The results of the present study indicate the urgent need for appropriate steps to be taken to improve the nutritional status of the children of these areas.
\end{abstract}

KEYWORDS: Prevalence, Stunting, Underweight, Wasting, $\chi^{2}$ - test, Z- scores, Z-test.

INTRODUCTION: Preschool children are nutritionally the most vulnerable because of rapid growth. In the developing world, 146 million children are underweight and more than half of them live in South East Asia. Out of 146 million, 57 million live in India. ${ }^{1}$

Undernutrition includes being underweight for one's age, too short for one's age (stunted), dangerously thin (wasted) and also deficient in vitamins and minerals. According to National Family Health Survey III, the prevalence of underweight, stunted and wasted in less than three years of age were $40 \%, 45 \%$ and $23 \%$ respectively in India. ${ }^{2}$

There are many causes of undernutrition and these are mainly lack of adequate intake of food, particularly so in the first three years when rapid growth occurs, quality of child care, high prevalence of communicable diseases.3,4,5

It is also found that the work status of the mother plays an important role in determining the health and nutrition status of the child. Child care time may be an important factor in determining the growth and wellbeing of the child. ${ }^{6}$

In view of the above the present study was carried out to assess the nutritional status of preschool children in the urban slums of Dibrugarh. 
MATERIALS AND METHODS: Sampling: The present study had been designed as a population based cross-sectional study which was carried out in the slums of Dibrugarh town during July, 2007 to June, 2008 amongst the preschool children aged 1-5 years.

Considering the prevalence of malnutrition in Assam amongst the preschool children to be $36 \%$ (GOI, NFHS II) and taking 95\% confidence interval $(z=1.96)$, relative error of $15 \%$ as allowable error and 5\% non-responses, sample size was calculated to be (304 \pm 15$)$. There are 10 registered slum areas in Dibrugarh town. All the slums were included in the study. Number of children included from each slum area was determined using proportional allocation. Assuming that there was at least one child in each household, a total of 319 households had been selected from the ten slum areas. In the slums systematic sampling was used to select the households. In the selected household, all the children aged one to five years were included for the study and the process was repeated till the required sample size was obtained. However, those children with visible physical deformities or clinical evidence of endocrine or other systemic disease or with major surgical operation likely to affect their growth were excluded from the study. The children with persistent diarrhea (Duration $>14$ days) in the last one month were also not included in the study.

DATA COLLECTION: The data had been collected by using a pre-structured and pre-tested oral questionnaire. For assessment of nutritional status by anthropometry, the different anthropometric indicators, based on the parameters weight, height and age were chosen according to the WHO Technical Report Series, 854 (WHO - 1995) for assessment of nutritional status and also to estimate the prevalence of malnutrition.

The anthropometric indicators, Weight-for-age, Height-for-age and Weight-for-height were expressed in Z-score relative to NCHS/CDC reference data (which was taken as "International reference" in most of the countries including India) published by WHO (1983). ${ }^{7}$

Children with weight for age $<-2$ SD of reference median were considered as underweight. Those with height for age $<-2$ SD of reference median were considered as stunted and those whose weight for height were $<-2$ SD of reference median were considered as wasted. The data was compiled and statistically analyzed using $\chi^{2}$ - test and $\mathrm{Z}$ test.

RESULTS: In the present study a total of 317 households were visited to meet the required sample size. In the selected households a total of 320 children were assessed for their nutritional status and included in the study. During the selection 7 non-respondents were found and they were replaced.

The distribution of children as per weight for age revealed that $20.43 \%$ of male children and $21.54 \%$ of female children were below -3 Standard Deviation whereas $37.10 \%$ of male children and $39.23 \%$ of female children were between -2.99 to -2 Standard Deviation. It had also been observed that the prevalence of underweight amongst the male was $57.75 \%$, whereas the same was $61.65 \%$ amongst the female children. However, this difference in the prevalence of underweight between the sexes was found to be statistically insignificant ( $p>0.05)$.

It had been observed from Table-2 for distribution of children as per height for age that $22.46 \%$ of male children and $40.60 \%$ of female children were below -3 Standard Deviation. Also it had been revealed that $22.46 \%$ of male children and $24.06 \%$ of female children were between -2.99 to -2 Standard Deviation. The prevalence of stunting amongst the male and female children was observed to be $44.92 \%$ and $64.66 \%$ respectively. Also, it had been found that the 
difference in the prevalence of stunting between the male and female children was statistically significant $(\mathrm{p}<0.01)$.

From Table-3, distribution of children as per weight for height had been observed that only $1.60 \%$ of male children were below -3 SD whereas $24.07 \%$ of male children and $6.77 \%$ of female children were between -2.99 to -2 Standard Deviation. The overall prevalence of wasting amongst the male was observed to be $25.67 \%$ whereas the same was only $6.77 \%$ amongst the female children and this difference in the prevalence of wasting between the sexes was found to be statistically significant $(\mathrm{p}<0.01)$.

In the present study we found an overall prevalence of underweight among the preschool children is $58.86 \%$. The prevalence of stunting was significantly higher among the children of illiterate mothers (58.55\%) as compared to the children of literate mothers (48.19\%). The prevalence of underweight, stunting and wasting were higher among the children of working mothers. Underweight was found to be higher in class III socio-economic group (68.67\%), followed by class IV (58.06\%) and class II (49.02\%), although statistically not significant. Stunting was found to be significantly higher in class III socio-economic group $(65.06 \%)$ and wasting was found to significantly higher in class IV socio-economic group.

DISCUSSION: In the present study overall undernutrition was $59.37 \%$, as compared to the NFHS III (2005-2006), which was 40.4\% in Assam. Onis M. de et al (1993) in his study observed that $35.8 \%$ of children under five years of age in developing countries were underweight. However, in India the percentage of underweight children was reported to be $63.9 \%{ }^{8}$

We found an overall prevalence of stunting was $53.12 \%$, which was similar to the finding of NFHS III (50.2\%). The prevalence of wasting was $17.81 \%$ as compared to the $13.3 \%$ in NFHS -III, (2005-06).

Study done in developing countries found that the prevalence of stunted and wasted children was $43 \%$ and $9.2 \%$ respectively; whereas in India, the same was reported to be $62.1 \%$ and $19.2 \%$ respectively. ${ }^{8}$ These findings were similar with the present study.

Study carried out in the slum areas of Udaypur city reported a higher prevalence of underweight (66\%), and wasting (30\%) and a less prevalence of stunting (42\%) as compared to the present study. ${ }^{5}$ Mittal, A et al (2007) found a lower prevalence of underweight (38.38\%) and that of stunting $(46.03 \%)$ among the children aged 1-5 years in the slum areas of Tripuri town, Patiala. $^{9}$

In the present study it was revealed that mother's education was inversely related to the prevalence of underweight, stunting and wasting. Mittal, A et al (2007) also found that prevalence of undernutrition and stunting was higher amongst the children of illiterate mothers. ${ }^{9}$

In the present study it was observed that mothers engagement in some occupation adversely affect the nutritional status of the children. Abbi R et al (1991), in a study conducted amongst rural children aged 0-6 years, in Chandrapur district of Maharastra, observed that the relative risk of having a low weight for age was significantly higher for children under three years of age and higher (but not significant) for older children aged (37-72 months) of working mothers as compared to the children of non-working mothers. ${ }^{10}$

In the present study we found a higher prevalence of stunting amongst children of class III socioeconomic group (65.06\%), followed by class IV (52.15\%), then class II $(37.25 \%)$. Wasting was higher in class IV socioeconomic group (22.58\%), followed by class II (11.76\%), 
then class III (10.84). The findings were comparable to the study conducted by D. Bhanderi et. al in Petlad town of Gujarat.11

CONCLUSION: Thus, from the present study and also from the studies cited above, it had been revealed that the overall prevalence of different forms of undernutrition among the preschool children was very high. Although many nutritional programs have been implemented by the Government of India during the last five decades to combat malnutrition in children, there was an urgent need for appropriate steps to be taken to improve the nutritional status of the children as a whole. It was also revealed from the present study that the working status of the mothers had a negative impact on the nutritional status of their children.

RECOMMENDATIONS: Thus, the results of the present study highly suggest for a strong need for educating the mothers about timely weaning and weaning foods which were easily available in the local market, that too at low cost. The poor nutritional status amongst children of working mothers suggests that crèche should be provided in urban slums, where her child can be taken care of by some other in absence of eligible elder member in the family. Most of the working women were engaged as maidservant or daily wager. So, they have limited capacity to buy more nutritious food for the family. They should also be taught regarding the cooking and hygienic practices.

\section{REFERENCES:}

1. UNICEF, Progress for Children, A report card on nutrition, Number 4, May 2006.

2. NFHS- III: Government of India, National Family Health Survey- III (2005-06), IIPS, Ministry of Health and Family Welfare, 2007.

3. Ghosh S: "Nutrition and Child Care", $2^{\text {nd }}$ Edition, 2006; page- 128.

4. Ramalingoswami V: "Malnutrition: A South Asian Enigma, Malnutrition in South Asia", ROSA Publication No.- 5, November, 1997, page- 11.

5. Tripathi M S, Sharma V: "Assessment of nutritional status of preschoolers in slum areas of Udaipur city", Journal of the Indian Public Health Association, Vol- 50, No- 1, JanuaryMarch 2006, Page 33.

6. Gopaldas T, Petal P, Bakshi M: "Women and nutrition: Selected socio-economic, environmental, maternal and child factors associated with the nutritional status of infants and toddlers", Food and Nutrition Bulletin, 1988, 10 (4), 29-34.

7. NCHS standards- Measuring changes in Nutritional status, WHO, Geneva, 1983.

8. Onis M. de, Monteiro C, Akre J, Clugston G: "The worldwide magnitude of protein- energy malnutrition: an overview from the WHO Global Database on child Growth", Bulletin of WHO, 71(6), 703-712, 1993.

9. Mittal A, Singh J, Ahluwalia S K: " Effect of maternal factors on nutritional status of 1-5 year old children in urban slum population", Indian Journal of Community Medicine, Vol32, No.- 4; 264-267, 2007.

10. 10) Abbi Rita, Christian P, Gujral S, Gopaldas T: "Impact of maternal work status on the nutrition and health status of children", Food and Nutrition Bulletin, 113 (1), 20-25; 1991.

11. D. Bhanderi, S. K. Choudhary, "An epidemiological study of health and nutritional status of under five children in semiurban community of Gujarat", IPHA Journal; Vol. xxxxx; No. 4; October-December, 2006. 
ORIGINAL ARTICLE

TABLE-1: DISTRIBUTION OF CHILDREN BY Z-SCORE (WEIGHT FOR AGE

\begin{tabular}{|l|l|l|l|l|l|l|l|l|l|l|}
\hline \multirow{2}{*}{$\begin{array}{l}\text { Z-SCORE } \\
\boldsymbol{\nabla}\end{array}$} & 1-2 YEARS & \multicolumn{2}{l|}{ 2-3 YEARS } & \multicolumn{2}{l|}{ 3-4 YEARS } & \multicolumn{2}{l|}{ 4-5 YEARS } & \multicolumn{2}{l|}{ TOTAL } \\
\cline { 2 - 10 } & $\mathrm{M}$ & $\mathrm{F}$ & $\mathrm{M}$ & $\mathrm{F}$ & $\mathrm{M}$ & $\mathrm{F}$ & $\mathrm{M}$ & $\mathrm{F}$ & $\mathrm{M}$ & $\mathrm{F}$ \\
\hline$\leq-3$ & 10 & -- & 16 & 16 & 3 & 3 & 10 & 12 & 39 & 31 \\
& $(23.81)$ & & $(38.10)$ & $(45.71)$ & $(5.17)$ & $(8.57)$ & $(22.22)$ & $(23.53)$ & $(20.86)$ & $(23.31)$ \\
\hline-2.99 to - & 22 & -- & 13 & -- & 22 & 19 & 12 & 32 & 69 & 51 \\
2 & $(52.38)$ & & $(30.95)$ & & $(37.93)$ & $(54.28)$ & $(26.67)$ & $(62.75)$ & $(36.90)$ & $(38.35)$ \\
\hline-1.99 to - & 10 & 12 & 10 & 16 & 29 & 12 & 22 & 6 & 71 & 46 \\
1 & $(23.81)$ & $(100)$ & $(23.81)$ & $(45.71)$ & $(50.00)$ & $(34.29)$ & $(48.89)$ & $(11.76)$ & $(37.97)$ & $(34.59)$ \\
\hline-0.99 to & -- & -- & 1 & 1 & 3 & -- & 1 & -- & 5 & 1 \\
MEDIAN & & & $(2.38)$ & $(2.86)$ & $(5.17)$ & & $(2.22)$ & & $(2.67)$ & $(0.75)$ \\
\hline+0.01 to 1 & -- & -- & 2 & -- & - & -- & -- & 1 & 2 & 1 \\
& & & $(4.76)$ & & & & & $(1.96)$ & $(1.07)$ & $(0.75)$ \\
\hline$>1$ & -- & -- & -- & 2 & 1 & 1 & -- & -- & 1 & 3 \\
& & & & $(5.72)$ & $(1.73)$ & $(2.86)$ & & & $(0.53)$ & $(2.25)$ \\
\hline TOTAL & 42 & 12 & 42 & 35 & 58 & 35 & 45 & 51 & 187 & 133 \\
& $(100)$ & $(100)$ & $(100)$ & $(100)$ & $(100)$ & $(100)$ & $(100)$ & $(100)$ & $(100)$ & $(100)$ \\
\hline
\end{tabular}

TABLE-2: DISTRIBUTION OF CHILDREN BY Z-SCORE (HEIGHT FOR AGE)

\begin{tabular}{|c|c|c|c|c|c|c|c|c|c|c|}
\hline \multirow{2}{*}{$\begin{array}{c}\text { Z- } \\
\text { SCORE } \\
\nabla\end{array}$} & \multicolumn{2}{|c|}{ 1-2 YEARS } & \multicolumn{2}{|c|}{ 2-3 YEARS } & \multicolumn{2}{|c|}{ 3-4 YEARS } & \multicolumn{2}{|c|}{ 4-5 YEARS } & \multicolumn{2}{|c|}{ TOTAL } \\
\hline & MALE & FEMALE & MALE & FEMALE & MALE & FEMALE & MALE & FEMALE & Male & FEMALE \\
\hline$\leq-3$ & $\begin{array}{c}16 \\
(38.10)\end{array}$ & -- & $\begin{array}{c}10 \\
(23.81)\end{array}$ & $\begin{array}{c}22 \\
(62.86)\end{array}$ & $\begin{array}{c}10 \\
(17.24)\end{array}$ & $\begin{array}{c}10 \\
(28.57)\end{array}$ & $\begin{array}{c}6 \\
(13.33)\end{array}$ & $\begin{array}{c}22 \\
(43.14)\end{array}$ & $\begin{array}{c}42 \\
(22.46)\end{array}$ & $\begin{array}{c}54 \\
(40.60)\end{array}$ \\
\hline $\begin{array}{c}-2.99 \text { to } \\
-2\end{array}$ & $\begin{array}{c}10 \\
(23.81)\end{array}$ & $\begin{array}{c}3 \\
(25.00)\end{array}$ & $\begin{array}{c}10 \\
(23.81)\end{array}$ & $\begin{array}{c}3 \\
(8.57)\end{array}$ & $\begin{array}{c}16 \\
(27.59)\end{array}$ & $\begin{array}{c}16 \\
(45.72)\end{array}$ & $\begin{array}{c}6 \\
(13.33)\end{array}$ & $\begin{array}{c}10 \\
(19.61)\end{array}$ & $\begin{array}{c}42 \\
(22.46)\end{array}$ & $\begin{array}{c}32 \\
(24.06)\end{array}$ \\
\hline $\begin{array}{c}-1.99 \text { to } \\
-1\end{array}$ & $\begin{array}{c}13 \\
(30.95)\end{array}$ & $\begin{array}{c}9 \\
(75.00)\end{array}$ & $\begin{array}{c}10 \\
(23.81)\end{array}$ & -- & $\begin{array}{c}16 \\
(27.59)\end{array}$ & $\begin{array}{c}6 \\
(17.14)\end{array}$ & $\begin{array}{c}26 \\
(57.78)\end{array}$ & $\begin{array}{c}16 \\
(31.37)\end{array}$ & $\begin{array}{c}65 \\
(34.76)\end{array}$ & $\begin{array}{c}31 \\
(23.31)\end{array}$ \\
\hline $\begin{array}{l}-0.99 \text { to } \\
\text { Median }\end{array}$ & $\begin{array}{c}3 \\
(7.14)\end{array}$ & -- & $\begin{array}{c}11 \\
(26.19)\end{array}$ & $\begin{array}{c}6 \\
(17.14)\end{array}$ & $\begin{array}{c}13 \\
(22.41)\end{array}$ & $\begin{array}{c}3 \\
(8.57)\end{array}$ & $\begin{array}{c}7 \\
(15.56)\end{array}$ & $\begin{array}{c}2 \\
(3.92)\end{array}$ & $\begin{array}{c}34 \\
(18.18)\end{array}$ & $\begin{array}{c}11 \\
(8.27)\end{array}$ \\
\hline $\begin{array}{c}+0.01 \text { to } \\
1\end{array}$ & -- & -- & $\begin{array}{c}1 \\
(2.38)\end{array}$ & $\begin{array}{c}1 \\
(2.86)\end{array}$ & $\begin{array}{c}3 \\
(5.17)\end{array}$ & -- & -- & $\begin{array}{c}1 \\
(1.96)\end{array}$ & $\begin{array}{c}4 \\
(2.14)\end{array}$ & $\begin{array}{c}2 \\
(1.50)\end{array}$ \\
\hline$>1$ & -- & -- & -- & $\begin{array}{c}3 \\
(8.57)\end{array}$ & -- & -- & -- & -- & -- & $\begin{array}{c}3 \\
(2.26)\end{array}$ \\
\hline TOTAL & $\begin{array}{c}42 \\
(100)\end{array}$ & $\begin{array}{c}12 \\
(100)\end{array}$ & $\begin{array}{c}42 \\
(100)\end{array}$ & $\begin{array}{c}35 \\
(100)\end{array}$ & $\begin{array}{c}58 \\
(100)\end{array}$ & $\begin{array}{c}35 \\
(100)\end{array}$ & $\begin{array}{c}45 \\
(100)\end{array}$ & $\begin{array}{c}51 \\
(100)\end{array}$ & $\begin{array}{c}187 \\
(100)\end{array}$ & $\begin{array}{c}133 \\
(100)\end{array}$ \\
\hline
\end{tabular}


Table 3: DISTRIBUTION OF CHILDREN BY Z-SCORE (WEIGHT FOR HEIGHT)

\begin{tabular}{|c|c|c|c|c|c|c|c|c|c|c|}
\hline \multirow{2}{*}{$\begin{array}{l}\text { Z-SCORE } \\
\nabla\end{array}$} & \multicolumn{2}{|c|}{ 1-2 YEARS } & \multicolumn{2}{|c|}{ 2-3 YEARS } & \multicolumn{2}{|c|}{ 3-4 YEARS } & \multicolumn{2}{|c|}{ 4-5 YEARS } & \multicolumn{2}{|l|}{ TOTAL } \\
\hline & $M$ & $\mathrm{~F}$ & $\mathrm{M}$ & $\mathrm{F}$ & $\mathrm{M}$ & $\mathrm{F}$ & $\mathrm{M}$ & $\mathrm{F}$ & $\mathrm{M}$ & $\mathrm{F}$ \\
\hline$\leq-3$ & $\begin{array}{c}3 \\
(7.14)\end{array}$ & -- & -- & -- & -- & -- & -- & -- & $\begin{array}{c}3 \\
(1.60)\end{array}$ & -- \\
\hline-2.99 to -2 & $\begin{array}{c}6 \\
(14.29 \\
)\end{array}$ & -- & $\begin{array}{c}13 \\
(30.95)\end{array}$ & $\begin{array}{c}6 \\
(17.14)\end{array}$ & $\begin{array}{c}10 \\
(17.24)\end{array}$ & -- & $\begin{array}{c}16 \\
(35.56 \\
)\end{array}$ & $\begin{array}{c}3 \\
(5.88)\end{array}$ & $\begin{array}{c}45 \\
(24.07)\end{array}$ & $\begin{array}{c}9 \\
(6.77)\end{array}$ \\
\hline-1.99 to -1 & $\begin{array}{c}19 \\
(45.24 \\
)\end{array}$ & $\begin{array}{c}6 \\
(50.0 \\
0)\end{array}$ & $\begin{array}{c}16 \\
(38.10)\end{array}$ & $\begin{array}{c}13 \\
(37.15)\end{array}$ & $\begin{array}{c}29 \\
(50.00)\end{array}$ & $\begin{array}{c}13 \\
(37.15)\end{array}$ & $\begin{array}{c}16 \\
(35.56 \\
)\end{array}$ & $\begin{array}{c}26 \\
(50.98)\end{array}$ & $\begin{array}{c}80 \\
(42.78)\end{array}$ & $\begin{array}{c}58 \\
(43.61)\end{array}$ \\
\hline $\begin{array}{l}-0.99 \text { to } \\
\text { Median }\end{array}$ & $\begin{array}{c}13 \\
(30.95 \\
)\end{array}$ & $\begin{array}{c}6 \\
(50.0 \\
0)\end{array}$ & $\begin{array}{c}13 \\
(30.95)\end{array}$ & $\begin{array}{c}3 \\
(8.57)\end{array}$ & $\begin{array}{c}16 \\
(27.59)\end{array}$ & $\begin{array}{c}16 \\
(45.71)\end{array}$ & $\begin{array}{c}13 \\
(28.88 \\
)\end{array}$ & $\begin{array}{c}19 \\
(37.26)\end{array}$ & $\begin{array}{c}55 \\
(29.41)\end{array}$ & $\begin{array}{c}44 \\
(33.08)\end{array}$ \\
\hline+0.01 to 1 & $\begin{array}{c}1 \\
(2.38)\end{array}$ & -- & -- & $\begin{array}{c}10 \\
(28.57)\end{array}$ & $\begin{array}{c}3 \\
(5.17)\end{array}$ & $\begin{array}{c}6 \\
(17.14)\end{array}$ & -- & $\begin{array}{c}3 \\
(5.88)\end{array}$ & $\begin{array}{c}4 \\
(2.14)\end{array}$ & $\begin{array}{c}19 \\
(14.28)\end{array}$ \\
\hline$>1$ & -- & -- & -- & $\begin{array}{c}3 \\
(8.57)\end{array}$ & -- & -- & -- & -- & -- & $\begin{array}{c}3 \\
(2.26)\end{array}$ \\
\hline TOTAL & $\begin{array}{c}42 \\
(100)\end{array}$ & $\begin{array}{c}12 \\
(100)\end{array}$ & $\begin{array}{c}42 \\
(100)\end{array}$ & $\begin{array}{c}35 \\
(100)\end{array}$ & $\begin{array}{c}58 \\
(100)\end{array}$ & $\begin{array}{c}35 \\
(100)\end{array}$ & $\begin{array}{c}45 \\
(100)\end{array}$ & $\begin{array}{c}51 \\
(100)\end{array}$ & $\begin{array}{c}187 \\
(100)\end{array}$ & $\begin{array}{c}133 \\
(100)\end{array}$ \\
\hline
\end{tabular}

Table 4: Prevalence of underweight, stunting and wasting in relation to the literacy and socioeconomic status of mother

\begin{tabular}{|c|c|c|c|c|}
\hline \multicolumn{2}{|l|}{$\mathrm{N}=320$} & $\begin{array}{c}\text { Underweight } \\
190(59.37 \%)\end{array}$ & $\begin{array}{c}\text { Stunting } \\
170(53.12 \%)\end{array}$ & $\begin{array}{c}\text { Wasting } \\
57(17.81 \%)\end{array}$ \\
\hline \multicolumn{5}{|c|}{ Literacy status of mother } \\
\hline Literate & 166 & $86(51.80)$ & $80(48.19)$ & $24(14.46)$ \\
\hline Illiterate & 154 & $104(67.53)$ & $90(58.55)$ & $33(21.43)$ \\
\hline $\mathrm{X}^{2}$ value (df) & & $8.77(1)$ & $3.22(1)$ & $3.07(1)$ \\
\hline P value & & $<.10$ & $<.01$ & $<.10$ \\
\hline \multicolumn{5}{|c|}{ Working status of mother } \\
\hline Working & 67 & $42(62.68)$ & 41 (61.19) & $19(28.35)$ \\
\hline Non-working & 253 & $148(58.50)$ & $129(50.98)$ & $38(15.02)$ \\
\hline $\mathrm{X}^{2}$ value (df) & & $0.42(1)$ & $1.85(1)$ & $6.49(1)$ \\
\hline p-value & & $>.05$ & $>.05$ & $<.001$ \\
\hline \multicolumn{5}{|c|}{ Socio-economic status } \\
\hline Class II & 51 & $25(49.02)$ & $19(37.25)$ & $6(11.76)$ \\
\hline Class III & 83 & $57(68.67)$ & $54(65.06)$ & $9(10.84)$ \\
\hline Class IV & 186 & $108(58.06)$ & $97(52.15)$ & $42(22.58)$ \\
\hline $\mathrm{X}^{2}$ value (df) & & $5.34(2)$ & $9.96(2)$ & $7.12(2)$ \\
\hline$P$ value & & $<.10$ & $<.01$ & $<.05$ \\
\hline
\end{tabular}

